\title{
Pemilihan Parameter Terbaik pada Algoritma Winnowing dalam Mendeteksi Tingkat Kesamaan Dokumen Bahasa Indonesia
}

\author{
Selection of the Best Parameters in the Winnowing Algorithm in Detecting \\ the Level of Similarity in Indonesian Documents \\ Wahyu Hidayat*1, Ema Utami ${ }^{2}$, Anggit Dwi Hartanto ${ }^{3}$ \\ 1,2,3 Magister Teknik Informatika Universitas Amikom Yogyakarta \\ E-mail: *11 wahyu.1181@students.amikom.ac.id, ${ }^{2}$ ema.u@amikom.ac.id, \\ 3anggit@amikom.ac.id
}

\begin{abstract}
Abstrak
Pengidentifikasian terkait plagiarisme terhadap dokumen berbahasa Indonesia telah dilakukan di penelitian terkait, untuk pendeteksi tingkat kesamaan dokumen. Dalam penelitian tersebut telah digunakan algoritma pendeteksi kesamaan dokumen dengan metode fingerprint sseperti Algoritma Winnowing. Algoritma Winnowing memiliki perbedaan pada penggunaan parameter seperti ada yang menggunakan k-gram dan n-gram. Dari perbedaan parameter tersebut dilakukan penelitian performa dari perbandingan penggunaan parameter yang berbeda pada pemotongan string pada tahap algoritma Winnowing sehingga dapat diketahui parameter yang mempunyai tingkat performa yang paling baik. Hasil penelitian pada k-gram memiliki tingkat nilai similarity yang tinggi namun ketika nilai jumlah $k$ semakin besar akan mengurangi tingkat nilai similarit dengan rata-rata hasil pada $k=2$ sebesar $0.5299, k=3$ sebesar $0.1689, k$ $=5$ sebesar 0.0283 dan $k=7$ sebesar 0.0095. Penerapan pemotongan string $n$-gram pada unigram memiliki rata-rata tingkat similarity sebesar 0.0683, bigram 0.003, pada trigram dan four-gram sebesar 0.000. Pada perbandingan kecepatan pemrosesan waktu k-gram dan n-gram tidak terlihat perbedaan yang signifikan dan keduanya mendominasi selama 6 detik.
\end{abstract}

Kata Kunci-Algoritma Winnowing, Jaccard Similarity, Fingerprint, K-gram, N-gram

\begin{abstract}
Identification related to plagiarism of Indonesian language documents has been carried out in related research, such as for the purpose of detecting the level of similarity documents. In this research, algorithm similarity detection algorithms have been used, especially with the fingerprint method wich Winnowing algorithm. Winnowing algorithm using parameters such as those using k-gram and n-gram. From these different parameters, a study of the performance of the comparison the use of different parameters in the string cutting at the Winnowing algorithm stage can be found out which parameter has the best level of performance. The results of research on $k$-gram have a high level of similarity value, but when the value of the number of $k$ gets bigger it will reduce the level of similarity values with an average result at $k=2$ of $0.5299, k=3$ of $0.1689, k=5$ of 0.0283 and $k=7$ in the amount of 0.0095. The application of cutting $n$-gram strings on unigram has an average similarity level of 0.0683, bigram 0.003, on trigrams and fourgrams of 0.000. In the comparison of the processing speed of k-gram and n-gram time, there was no significant difference, and both dominated for 6 seconds.
\end{abstract}

Keywords - Winnowing algorithm, Jaccard Similarity, Fingerprint, K-gram, N-gram 


\section{PENDAHULUAN}

Plagiarisme yang dilakukan dalam penulisan bukan merupakan hal baru yang terjadi khususnya pada dokumen berbahasa Indonesia [1]. Penulis sering mengutarakan sebuah kata yang mirip dengan apa yang telah di tulis oleh orang lain, meskipun telah menambah kata sambung atau merubah letak penulisan tetap di identifikasi sebagai plagiarisme karena penulis tidak memparafrasa ulang terkait dengan makna yang sama namun dengan penulisan yang berbeda. Permasalahan tingkat kepentingan plagiarisme tergantung terhadap jenis dokumen yang diteliti, namun pada dasarnya melakukan plagiarisme merupakan pelanggaran etika. Selain itu melakukan plagiarisme merupakan hal yang melanggar hukum terkait dengan kerugian yang didampakkannya, karena perbuatan tersebut merupakan perbuatan yang tidak terpuji [2].

Tentang penambahan kata sambung dan kata imbuhan pada dokumen yang mirip jika di lihat secara manual memiliki penempatan kata yang berbeda seperti pembuatan kata tersebut ke kata langsung dan tidak langsung serta pengimbuhan kata sehingga seolah-olah penulisan dokumen tersebut berbeda. Namun hal tersebut dapat diteliti dengan menggunakan text preprocessing karena terdapat proses yang dapat menghilangkan kata sambung serta dapat merubah kata berimbuhan menjadi kata baku dalam prosesnya. Maka dari itu text preprocessing tersebut dapat mentransformasikan sebuah dokumen yang semulanya memiliki susunan kata menjadi sekumpulan kata tanpa mengurangi makna [3]. Algoritma Nazief \& Adriani merupakan algoritma stemming yang digunakan untuk mengolah kata berimbuhan menjadi kata baku berdasarkan aturan pada algoritma tersebut [4]. Penerapan algoritma Nazief \& Adriani bertujuan untuk mengidentifikasi kata dasar berdasarkan aturan [5], aturan tersebut didasarkan pada aturan morfologi bahasa Indonesia yang mengidentifikasi kata berimbuhan kedalam aturannya kemudian dicocokkan dengan kamus Bahasa Indonesia [6].

Algoritma Winnowing merupakan algoritma pendeteksi tingkat kesamaan dokumen, salah satu langkah dari algoritma winnowing yaitu mentransformasikan sebuah kata menjadi sebanyak ukuran k-gram ataupun n-gram, jika menggunakan k-gram didasarkan pada sekumpulan per karakter yang dipotong berdasarkan jumlah $k$ [7] namun terdapat pemotongan berdasarkan pemenggalan kata dengan metode memotong berdasarkan unigram, bigram, trigram, four-gram [8]. Setelah pemotongan berdasarkan jumlah k-gram ataupun n-gram selanjutnya pembuatan hashing pada setiap pemotongan tersebut menggunakan rolling hash [9]. Dari hasil rolling hash tersebut di kelompokkan menjadi beberapa window dengan anggota window yang ditentukan, setelah dikelompokkan maka akan diidentifikasi nilai terkecil dari setiap window yang akan menjadi nilai fingerprint. Berdasarkan nilai terkecil atau fingerprint pada setiap window kemudian dicocokkan antar fingerprint dokumen lainnya, dari jumlah fingerprint yang sama dan akumulasi jumlah fingerprint di kedua dokumen yang dibandingkan akan di hitung dengan persamaan Jaccard Similarity [10] sehingga akan ditemukan nilai kesamaan antar dokumen tersebut.

Dalam menyelesaikan permasalahan pendeteksi kesamaan dokumen [11] melakukan penelitian tentang mengukur tingkat kemiripan dokumen pada pengajuan proposal menggunakan algoritma Winnowing dengan biword. Pemakaian biword didasarkan pada pemotongan kata yang di potong berdasarkan per dua kata yang mempunyai tujuan menjaga arti kata pada dokumen yang di proses. Pada penelitian tersebut menunjukkan hasil basis dan window terbaik yaitu basis 4 dan window 2 pada dataset penelitian sedangkan pada dataset pengabdian menghasilkan basis 2 dan window 1. Dalam penelitian yang dilakukan terdapat perbandingan dari hasil checker X yang dibandingkan dengan penerapan algoritma biword Winnowing yang menunjukkan hasil presentase rata-rata selisih $0.635 \%$ pada dataset penelitian sedangkan untuk dataset pengabdian memiliki rata-rata $0.586 \%$.

Penelitian terkait penggunaan biword pada penerapan algoritma Winnowing [12] yang membandingkan penerapan biword dan triword serta membandingkan algoritma fingerprint similarity dengan metode Winnowing dan Manber. Dataset yang digunakan menggunakan 10 dokumen abtrak yang berbeda, pada penerapan algoritma Winnowing menggunakan variasi jumlah window yang ditetapkan pada satu angka yaitu dengan nilai 4 untuk percobaan 
menggunakan biword dan triword. Pada perbandingan penerapan biword dan triword dalam algoritma Winnowing memiliki hasil nilai rata-rata similarity 94\% untuk penerapan biword dan 91.22\% untuk peneraan triword sedangkan dalam perbandingan algoritma Winnowing dan algoritma Manber menghasilkan kesimpulan bahwa algoritma Winnowing memiliki hasil tingkat kemiripan 94\% dan algoritma Manber 90.56\%. Jadi dalam penerapan perbandingan yang dilakukan, algoritma Winnowing dengan metode biword memiliki hasil yang paling baik dibandingkan dalam penerapan algoritma Winnowing dengan triword dan penerapan algoritma Manber.

Penerapan algoritma Winnowing lainnya yaitu [13] yang menerapkan pemotongan gram dengan jumlah gram 3, pada penelitian ini memotong berdasarkan huruf dengan pemotongan kgram atau bukan berdasarkan kata. Pada pemakaian jumlah window menggunakan nilai 2, pada pemilihan fingerprint dilakukan dengan memilih nilai terkecil pada setiap window namun jika terdapat nilai terkecil yang sama pada window berikutnya atau duplikasi nilai fingerprint maka hanya dipilih satu dari nilai yang sama tersebut. Pada penerapan algoritma Winnowing tersebut digunakan untuk memberikan rekomendasi pemilihan dosen pembimbing berdasarkan kata kunci yang dibandingkan. Namun pada penelitian tersebut tidak dilakukan perbandingan hasil tentang pemilihan nilai k-gram ataupun jumlah window. Pada penerapan sistem yang dibuat mampu menunjukkan persentase rekomendasi pemilihan dosen pembimbing dengan hasil untuk Saiful Bukhori memiliki nilai $16.67 \%$ dan Slamin memiliki nilai $1.18 \%$.

Pendeteksi kemiripan dokumen teks lainnya [14] menggunakan pemotongan berdasarkan karakter dengan jumlah $k$ pada pemotongan gram terhadap algoritma Winnowing. Pada penelitian tersebut pada penentuan fingerprint menggunakan pemilihan nilai window terkecil namun jika ada nilai yang sama maka akan dipilih nilai paling kanan dari window tersebut. Pada pencocokan yang dilakukan mengakumulasinya dengan Jaccard Similarity dengan menghitung berdasasarkan fingerprint pada kedua dokumen yang dibandingkan. Dalam pengujian yang dilakukan menggunakan nilai variasi k-gram dan w-gram sebanyak 6, 12, dan 24 serta diterapkan pada dataset yang berupa 2 file tugas akhir. Hasil rata-rata pada penerapan variasi k-gram dan w-gram menunjukkan bahwa penerapan nilai w-gram 6 menghasilkan nilai rata-rata tingkat similarity 12.40\%, nilai w-gram 12 menghasilkan 9.11\% dan nilai w-gram 24 menghasilkan nilai $8.42 \%$.

Pendeteksian plagiarisme lainnya diteliti oleh [15] dalam penelitian tersebut melakukan pengujian terhadap variasi nilai gram, window dan basis terhadap algoritma Winnowing. Dalam penerapannya menggunakan dataset yang berjumlah 5, dengan keterangan bahwa dokumen tersebut merupakan dokumen milik mahasiswa pada mata kuliah Metode Penelitian di STMIK Akba Makassar. Selanjutnya dalam penerapannya membandingkan kemungkinan perbandingan antara dokumen satu dengan yang lainnya, hasil dari penelitian tersebut menghasilkan pemilihan nilai gram 8, window 6 dan basis 23 yang diterapkan pada dataset yang diteliti karena pada pengujian sebelumnya ketika menggunakan nilai basis 2 hasil dari tingkat presentase tidak stabil.

Berdasarkan perbedaan pemakaian langkah dan parameter dari penelitian sebelumnya maka akan diteliti mengenai perbandingan pemakaian parameter pada penerapan k-gram dengan nilai bilangan prima 2, 3, 5 dan 7 serta menerapkan n-gram dengan pemotongan per-kata pada unigram, bigram, trigram dan four-gram sehingga dapat diketahui pemilihan parameter yang paling baik berdasarkan nilai tingkat kesamaannya dalam mendeteksi kesamaan dokumen.

\section{METODE PENELITIAN}

Dalam melakukan penelitian telah dibuatkan struktur penelitian supaya penelitian yang dilakukan dapat terarah sesuai tujuan. Berikut alur penelitian diuraikan pada Gambar 1. 


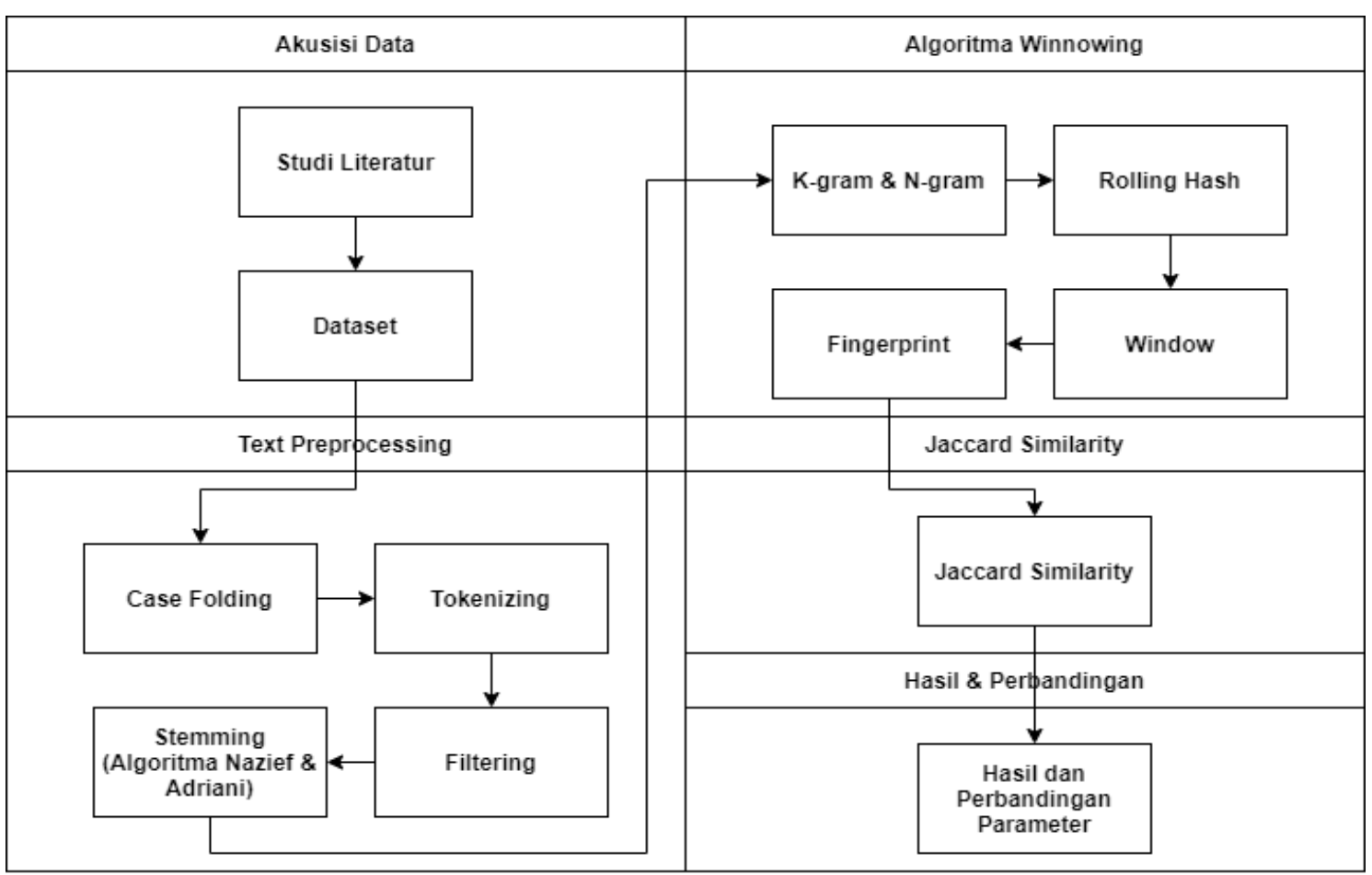

Gambar 1. Alur Penelitian

\subsection{Akusisi Data}

Pada penelitian ini dilakukan studi literatur untuk mengetahui topik penelitian dan pembuatan perumusan masalah. Setelah itu menggunakan dataset publik pada dataset dokumen Bahasa Indonesia.

\subsection{Text Preprocessing}

Pada pemrosesan teks terdapat beberapa langkah yaitu case folding untuk merubah semua huruf menjadi lowercase, tokenizing untuk membuat potongan kata berdasarkan spasi, filtering untuk membuang kata yang kurang penting, dan stemming untuk merubah kata menjadi kata baku [16]. Pada tahap stemming diterapkan algoritma Nazief \& Adriani dengan memiliki 6 langkah dalam penerapan aturan yaitu (1) mengecek kata terhadap kamus kata dasar, jika ditemukan maka proses berhenti, (2) Menghapus sufiks infleksi, sufiks infleksi tidak memengaruhi ejaan kata yang dilampirkan, dan sufiks infleksi ganda selalu muncul berurutan. (3) Menghapus semua sufiks derivatif \{"-i," "-kan," dan "-an"\}. (4) Menghapus semua awalan turunan \{"be-," "di-," "kem," "me-," "pe-," "se," dan "te-" \}. (5) Pengkodean ulang kata jika terjadi pemotongan yang tidak valid. (6) Jika semua langkah tidak berhasil, akan mengembalikan kata asli [17].

\subsection{Algoritma Winnowing}

Setelah membersihkan teks pada tahap preprocessing, selanjutnya memproses teks tersebut pada algoritma Winnowing sebagai berikut [18]:

1. Memotong Substring

Terdapat metode dalam memotong sebuah teks, yaitu k-gram dengan teknik pemotongan perkarakter dan n-gram dengan implementasi pemotongan berdasarkan perkata.

2. Rolling Hash

Berdasarkan perpotongan substring yang dilakukan, semua substring yang terbentuk akan diproses pada proses hashing dengan teknik Rolling Hash. Berikut persamaan 1 (Rolling Hash). 
Citec Journal, Vol. 7, No. 2, Juli 2020

$H_{(c 1 \ldots c k)}=c_{1} * b^{(k-1)}+c_{2} * b^{(k-2)}+\cdots+c_{(k-1)} * b^{k}+c_{k}$

Keterangan:

c: nilai ascii karakter

b: basis (bilangan prima)

k: banyak karakter

3. Window

Setelah dilakukan pembuatan hash pada setiap potongan substring, selanjutnya mengelompokkan hash tersebut kedalam window dengan jumlah anggota setiap window yang ditentukan dengan nilai window.

4. Fingerprint

Selanjutnya, mencari nilai fingerprint yaitu berdasarkan nilai hash terkecil dari setiap window, jika ada nilai terkecil yang sama maka diambil salah satu nilai yang paling kanan.

\subsection{Jaccard Similarity}

Setelah menentukan nilai fingerprint selanjutnya mencocokkan fingerprint yang sama, dan hasilnya diakumulasi dengan persamaan 2, Jaccard Similarity sebagai berikut [19]:

$$
J S(X, Y)=\frac{|\mathrm{X} \cap \mathrm{Y}|}{|\mathrm{X}|+|\mathrm{Y}|-|\mathrm{X} \cap \mathrm{Y}|}
$$

Keterangan:

$\mathrm{X}$ : fingerprint dokumen 1

Y: fingerprint dokumen 2

\subsection{Hasil \& Perbandingan}

Berdasarkan penerapan algoritma stemming Nazief \& Adriani, algoritma Winnowing serta Jaccard Similarity akan dilakukan perbandingan pada pemilihan parameter terbaik pada pemotongan substring menggunakan k-gram dan n-gram pada langkah algoritma Winnowing.

\section{HASIL DAN PEMBAHASAN}

\subsection{Akusisi Data}

Dataset yang digunakan pada penelitian ini merupakan dataset publik yang berasal dari Github https://github.com/anggamaulana/DocumentSimilarity yang merupakan dokumen abstrak dari penelitian terkait sebanyak 5 dokumen.

\subsection{Text Preprocessing}

Setelah melakukan akusisi data selanjutnya data tersebut diproses pada tahap text preprocessing. Dari tahap case folding untuk merubah huruf menjadi lowercase, tokenizing untuk memisah huruf berdasarkan spasi dan filtering untuk menghapus kata yang kurang penting, dan langkah terakhir dari text preprocessing yaitu stemming untuk merubah kata menjadi kata dasar, pada penelitian ini menggunakan penerapan algoritma stemming Nazief \& Adriani pada tahap stemming, hasil dari stemming ditampilkan pada Tabel 1. 
Tabel 1. Hasil Stemming

\begin{tabular}{ll}
\hline id & \multicolumn{1}{c}{ Stemming } \\
\hline 1 & ["modern","nakal","remaja","masyarakat","masyarakat","daerah","kota","nakal", \\
& $\ldots$ \\
& "akurasi"] \\
\hline 2 & ["masalah","pasca","panen","buah","belimbing","produksi","skala","industri", \\
& $\ldots$ \\
& "belimbing"] \\
\hline$\ldots$ & ... \\
\hline 5 & ["tempat","praktek","kerja","lapang","pkl","mahasiswa","maksimal","mampu", \\
& $\ldots$ \\
& "selatan"] \\
\hline
\end{tabular}

\subsection{Algoritma Winnowing.}

Tahap pertama dari algoritma Winnowing yaitu melakukan pemotongan dari string, pada penelitian ini dilakukan 2 tipe pemotongan yaitu menggunakan k-gram dan n-gram. K-gram menggunakan angka 2, 3, 5, dan 7 sedangkan pada n-gram menggunakan nilai unigram, bigram, trigram dan four-gram. Hasil dari pemotongan kata menggunakan k-gram berdasarkan per-huruf ditampilkan pada Tabel 2.

Tabel 2. Hasil Pemotongan String dengan K-Gram

\begin{tabular}{|c|c|c|c|c|}
\hline \multirow{2}{*}{ id } & \multicolumn{4}{|c|}{ k-gram } \\
\hline & $k=2$ & $k=3$ & $k=5$ & $k=7$ \\
\hline \multirow[t]{2}{*}{1} & $\begin{array}{l}\text { "mo", "od", "de", } \\
\text { "er", "rn", "nn", }\end{array}$ & $\begin{array}{l}\text { "mod", "ode", "der", } \\
\text { "ern", "rnn", "nna", }\end{array}$ & $\begin{array}{l}\text { "moder", "odern", } \\
\text { "dernn", "ernna", }\end{array}$ & $\begin{array}{l}\text { "modernn", } \\
\text { "odernna", }\end{array}$ \\
\hline & $\begin{array}{l}\ldots \\
\text { "si" }\end{array}$ & "... & ".. & "... \\
\hline \multirow[t]{3}{*}{2} & $\begin{array}{l}\text { "ma", "as", "sa", } \\
\text { "al", "la", "ah", }\end{array}$ & $\begin{array}{l}\text { "mas", "asa", "sal", } \\
\text { "ala", "lah", "ahp", }\end{array}$ & $\begin{array}{l}\text { "masal", "asala", } \\
\text { "salah", "alahp", }\end{array}$ & $\begin{array}{l}\text { "masalah", } \\
\text { "asalahp", }\end{array}$ \\
\hline & $\begin{array}{l}\text {... } \\
\text { "ng" }\end{array}$ & "... & $\begin{array}{l}\text { ".. } \\
\text { "mbing" }\end{array}$ & $\begin{array}{l}\text { "limbing" } \\
\text { "limg }\end{array}$ \\
\hline & $\ldots$ & $\ldots$ & $\ldots$ & $\ldots$ \\
\hline \multirow[t]{2}{*}{5} & $\begin{array}{l}\text { "te", "em", "mp", } \\
\text { "pa", "at", "tp", } \\
\text {.. }\end{array}$ & $\begin{array}{l}\text { "tem", "emp", } \\
\text { "mpa", "pat", "atp", } \\
\text { "tpr", }\end{array}$ & $\begin{array}{l}\text { "tempa", "empat", } \\
\text { "mpatp", "patpr", } \\
\text {... }\end{array}$ & $\begin{array}{l}\text { "tempatp", } \\
\text { "empatpr", } \\
\text {... }\end{array}$ \\
\hline & "an" & $\begin{array}{l}\ldots \\
\text { "tan" }\end{array}$ & "latan" & "selatan" \\
\hline
\end{tabular}

Selain menggunakan k-gram, dilakukan pemotongan string menggunakan n-gram dengan unigram, bigram, trigram dan fougram yang memotong string berdasarkan per-kata. Hasil dari ngram ditampilkan pada Tabel 3. 
Citec Journal, Vol. 7, No. 2, Juli 2020

Tabel 3. Hasil Pemotongan String dengan N-Gram

\begin{tabular}{|c|c|c|c|c|}
\hline \multirow{2}{*}{ id } & \multicolumn{4}{|c|}{ n-gram } \\
\hline & unigram & bigram & trigram & four-gram \\
\hline 1 & $\begin{array}{l}\text { "modern", "nakal", } \\
\text { "remaja", } \\
\text {... } \\
\text { "akurasi" }\end{array}$ & $\begin{array}{l}\text { "modern nakal", } \\
\text { "nakal remaja", } \\
\text {... } \\
\text { "tingkat akurasi" }\end{array}$ & $\begin{array}{l}\text { "modern nakal } \\
\text { remaja", "nakal remaja } \\
\text { masyarakat", } \\
\text {... } \\
\text { "hasil tingkat akurasi" }\end{array}$ & $\begin{array}{l}\text { "modern nakal } \\
\text { remaja } \\
\text { masyarakat", } \\
\text {... } \\
\text { "video hasil } \\
\text { tingkat akurasi" }\end{array}$ \\
\hline 2 & $\begin{array}{l}\text { "masalah", } \\
\text { "pasca", "panen", } \\
\text { "buah", } \\
\text {... "belimbing" }\end{array}$ & $\begin{array}{l}\text { "masalah pasca", } \\
\text { "pasca panen", } \\
\text {... } \\
\text { "buah belimbing" }\end{array}$ & $\begin{array}{l}\text { "masalah pasca } \\
\text { panen", "pasca panen } \\
\text { buah", } \\
\text {... } \\
\text { "citra buah belimbing" }\end{array}$ & $\begin{array}{l}\text { "masalah pasca } \\
\text { panen buah", } \\
\text {... } \\
\text { "fitur citra buah } \\
\text { belimbing" }\end{array}$ \\
\hline.. & $\ldots$ & $\ldots$ & $\ldots$ & $\ldots$ \\
\hline 5 & $\begin{array}{l}\text { "tempat", } \\
\text { "praktek", "kerja", } \\
\text {... } \\
\text { "selatan" }\end{array}$ & $\begin{array}{l}\text { "tempat praktek", } \\
\text { "praktek kerja", "kerja } \\
\text { lapang", } \\
\text {.. } \\
\text { "aceh selatan" }\end{array}$ & $\begin{array}{l}\text { "tempat praktek kerja", } \\
\text { "praktek kerja lapang", } \\
\text { "kerja lapang pkl", } \\
\text {... } \\
\text { "politeknik aceh } \\
\text { selatan" }\end{array}$ & $\begin{array}{l}\text { "tempat praktek } \\
\text { kerja lapang", } \\
\text {... } \\
\text { "komputer } \\
\text { politeknik aceh } \\
\text { selatan" }\end{array}$ \\
\hline
\end{tabular}

Setelah pemotongan string dengan k-gram dan n-gram selanjutnya dilakukan pengubahan string menjadi sebuah hash menggunakan rolling hash dengan basis nilai bilangan prima 11 . Berikut contoh perhitungan rolling hash dengan masukan string "mo" pada persamaan 3.

$$
\begin{aligned}
& H_{(m o)}=109 * 11^{(2-1)}+111 * 11^{(2-2)} \\
& H_{(m o)}=1310
\end{aligned}
$$

Berikut ditampilkan hasil rolling hash pada potongan k-gram yang sebelumnya telah diketahui, hasil dari perhitungan rolling hash ditampilkan pada Tabel 4.

\begin{tabular}{|c|c|c|c|c|}
\hline \multirow{2}{*}{ id } & \multicolumn{4}{|c|}{ k-gram } \\
\hline & $k=2$ & $k=3$ & $k=5$ & $k=7$ \\
\hline 1 & $\begin{array}{l}1310,1321,1201 \\
\ldots \\
1370\end{array}$ & $\begin{array}{l}14510,14632,13325 \ldots \\
13107\end{array}$ & $\begin{array}{l}\text { 1756935, 1771836, } \\
1613645 \\
\ldots \\
1877838\end{array}$ & $\begin{array}{l}212590455, \\
214393463, \\
195252219 \\
\ldots \\
190951712 \\
\end{array}$ \\
\hline 2 & $\begin{array}{l}1296,1182,1362 \\
\ldots \\
1313\end{array}$ & $\begin{array}{l}14371,13099,15090 \ldots \\
14018\end{array}$ & $\begin{array}{l}1740066,1586264, \\
1827061 \\
\ldots \\
1740325\end{array}$ & $\begin{array}{l}210549157, \\
191939200, \\
221075710 \\
\ldots \\
209979268\end{array}$ \\
\hline.. & $\ldots$ & $\ldots$ & $\ldots$ & $\ldots$ \\
\hline 5 & $\begin{array}{l}1377,1220,1311 \\
\ldots \\
1177\end{array}$ & $\begin{array}{l}15256,13532,14518 \ldots \\
15213\end{array}$ & $\begin{array}{l}\text { 1847305, } 1638555, \\
1758066 \\
\ldots \\
1725548\end{array}$ & $\begin{array}{l}223525293, \\
198266501, \\
212727337 \\
\ldots \\
221721214 \\
\end{array}$ \\
\hline
\end{tabular}

Tabel 4. Hasil Rolling Hash pada K-Gram. 
Pemotongan yang dihasilkan dari n-gram dilakukan juga perhitungan dengan rolling hash, hasil rolling hash pada n-gram ditampilkan pada Tabel 5.

Tabel 5. Hasil Rolling Hash pada N-Gram

\begin{tabular}{lllll}
\hline \multirow{2}{*}{ id } & \multicolumn{4}{c}{ n-gram } \\
\cline { 2 - 6 } & \multicolumn{1}{c}{ unigram } & \multicolumn{1}{c}{ bigram } & \multicolumn{1}{c}{ trigram } & \multicolumn{1}{c}{ four-gram } \\
\hline & 19326395, & 34237894559966, & $6.671997059701 \mathrm{e}+20$, & $1.903598627415 \mathrm{e}+32$, \\
& 1753739, & 34175488468955, & $9.7506657090256 \mathrm{e}+24$, & $2.7819787230115 \mathrm{e}+36$, \\
1 & 19996634 & $5.7052741634162 \mathrm{e}+18$ & $1.6277813028581 \mathrm{e}+30$ & $3.1720852599398 \mathrm{e}+37$ \\
& $\ldots$ & $\ldots$ & $\ldots$ & $\ldots$ \\
& 190951712 & $4.8053509399811 \mathrm{e}+16$ & $7.6596037971803 \mathrm{e}+22$ & $1.5309568521711 \mathrm{e}+29$ \\
\hline & 210549157, & $3.7300068206171 \mathrm{e}+14$, & $6.6079346131393 \mathrm{e}+20$, & $1.0642144773807 \mathrm{e}+26$, \\
& 1784000, & 3160471761062, & $5.0899713759141 \mathrm{e}+17$, & $1.3202074878402 \mathrm{e}+28$, \\
2 & 1783430 & 287223799208 & $7.4498456356689 \mathrm{e}+21$ & $1.7566346314932 \mathrm{e}+31$ \\
& $\ldots$ & $\ldots$ & $\ldots$ & $\ldots$ \\
& 23185353877 & $3.7808932740694 \mathrm{e}+15$ & $6.7028325227805 \mathrm{e}+21$ & $1.2199887882438 \mathrm{e}+28$ \\
\hline.. & $\ldots$ & $\ldots$ & $\ldots$ & $\ldots$ \\
\hline & 20320471, & $4.3558742668949 \mathrm{e}+15$, & $7.7166969721346 \mathrm{e}+21$, & $1.5037659345117 \mathrm{e}+29$, \\
& 218352494, & $3.8682476949284 \mathrm{e}+14$, & $7.5381204301427 \mathrm{e}+21$, & $1.1036562121772 \mathrm{e}+26$, \\
5 & 1716075 & 33441522639584 & $4.8961733296621 \mathrm{e}+17$ & $1.2699412657154 \mathrm{e}+28$ \\
& $\ldots$ & $\ldots$ & $\ldots$ & \\
& 221721214 & 30504328435867 & $1.0018315799464 \mathrm{e}+25$ & $2.2665573573324 \mathrm{e}+34$ \\
\hline
\end{tabular}

Setelah dilakukan perhitungan rolling hash pada k-gram dan n-gram selanjutnya dilakukan pembuatan window menggunakan ukuran window sebanyak 2. Hasil dari pembuatan window dari hash yang didapatkan di k-gram ditampilkan pada Tabel 6.

Tabel 6. Window pada Rolling Hash K-Gram

\begin{tabular}{|c|c|c|c|c|}
\hline \multirow{2}{*}{ id } & \multicolumn{4}{|c|}{ k-gram } \\
\hline & $k=2$ & $k=3$ & $k=5$ & $k=7$ \\
\hline \multirow[t]{3}{*}{1} & $\begin{array}{l}\{1310,1321\}, \\
\{1321,1201\}, \\
\{1201,1225\}\end{array}$ & $\begin{array}{l}\{14510,14632\}, \\
\{14632,13325\}, \\
\{13325,13585\}\end{array}$ & $\begin{array}{l}\{1756935,1771836\}, \\
\{1771836,1613645\}, \\
\{1613645,1645092\}\end{array}$ & $\begin{array}{l}\{212590455,214393463\}, \\
\{214393463,195252219\}, \\
\{195252219,199057406\}\end{array}$ \\
\hline & $\ldots$ & $\ldots$ & $\ldots$ & $\ldots$ \\
\hline & $\{1182,1370\}$ & $\{14976,13107\}$ & $\{1737290,1877838\}$ & $\{222860313,190951712\}$ \\
\hline \multirow[t]{2}{*}{2} & $\begin{array}{l}\{1296,1182\}, \\
\{1182,1362\}, \\
\{1362,1175\}\end{array}$ & $\begin{array}{l}\{14371,13099\}, \\
\{13099,15090\}, \\
\{15090,13022\}\end{array}$ & $\begin{array}{l}\{1740066,1586264\}, \\
\{1586264,1827061\}, \\
\{1827061,1576918\}\end{array}$ & $\begin{array}{l}\{210549157,191939200\}, \\
\{191939200,221075710\}, \\
\{221075710,190808260\}\end{array}$ \\
\hline & $\begin{array}{l}\ldots \\
\{1265,1313\}\end{array}$ & $\begin{array}{l}\cdots \\
\{13123,14018\}\end{array}$ & $\begin{array}{l}\ldots \\
\{1695507,1740325\}\end{array}$ & $\begin{array}{l}\ldots \\
\{198016676,209979268\}\end{array}$ \\
\hline & & & & \\
\hline \multirow[t]{2}{*}{5} & $\begin{array}{l}\{1377,1220\}, \\
\{1220,1311\}, \\
\{1311,1329\}\end{array}$ & $\begin{array}{l}\{15256,13532\}, \\
\{13532,14518\}, \\
\{14518,14735\}\end{array}$ & $\begin{array}{l}\{1847305,1638555\}, \\
\{1638555,1758066\}, \\
\{1758066,1784281\}\end{array}$ & $\begin{array}{l}\{223525293,198266501\}, \\
\{198266501,212727337\}, \\
\{212727337,215899175\}\end{array}$ \\
\hline & $\dddot{m} 1373,1177\}$ & $\cdots 13110,15213\}$ & $\ldots 1635599,1725548\}$ & $\ldots$ \\
\hline
\end{tabular}

Berikut hasil dari pembuatan window dari perhitungan rolling hash pada n-gram, hasil window ditampilkan pada Tabel 7. 
Citec Journal, Vol. 7, No. 2, Juli 2020

Tabel 7. Window pada Rolling Hash N-Gram

\begin{tabular}{|c|c|c|c|c|}
\hline \multirow{2}{*}{ id } & \multicolumn{4}{|c|}{ n-gram } \\
\hline & unigram & bigram & trigram & four-gram \\
\hline \multirow[t]{3}{*}{1} & $\begin{array}{l}\text { \{19326395, } \\
1753739\}, \\
\{1753739, \\
19996634\}, \\
\{19996634, \\
280281927580\}\end{array}$ & $\begin{array}{l}\{34237894559966, \\
34175488468955\}, \\
\{34175488468955, \\
5.7052741634162 \mathrm{e}+18\}, \\
\{5.7052741634162 \mathrm{e}+18, \\
7.9967705001031 \mathrm{e}+22\}\end{array}$ & $\begin{array}{l}\{6.671997059701 \mathrm{e}+20, \\
9.7506657090256 \mathrm{e}+24\}, \\
\{9.7506657090256 \mathrm{e}+24, \\
1.6277813028581 \mathrm{e}+30\} \\
\{1.6277813028581 \mathrm{e}+30, \\
1.5583443418327 \mathrm{e}+30\}\end{array}$ & $\begin{array}{l}1.903598627415 \mathrm{e}+32, \\
2.7819787230115 \mathrm{e}+36\}, \\
\{2.7819787230115 \mathrm{e}+36, \\
3.1720852599398 \mathrm{e}+37\} \\
\{3.1720852599398 \mathrm{e}+37, \\
2.5097291459649 \mathrm{e}+35\}\end{array}$ \\
\hline & & $\ldots$ & $\ldots$ & $\ldots$ \\
\hline & $\begin{array}{l}\{224173164, \\
190951712\}\end{array}$ & $\begin{array}{l}\{3.5732617008670 \mathrm{e}+14, \\
4.8053509399811 \mathrm{e}+16\}\end{array}$ & $\begin{array}{l}\{7.1420267032046 \mathrm{e}+20, \\
7.6596037971803 \mathrm{e}+22\}\end{array}$ & $\begin{array}{l}\{1.0794979859123 \mathrm{e}+27, \\
1.5309568521711 \mathrm{e}+29\}\end{array}$ \\
\hline \multirow[t]{3}{*}{2} & $\begin{array}{l}\{210549157, \\
1784000\}, \\
\{1784000, \\
1783430\}, \\
\{1783430, \\
145766\}\end{array}$ & $\begin{array}{l}\{3.7300068206171 \mathrm{e}+14, \\
3160471761062\}, \\
\{3160471761062, \\
287223799208\}, \\
\{287223799208, \\
3.7808932740694 \mathrm{e}+15\}\end{array}$ & $\begin{array}{l}\{6.6079346131393 \mathrm{e}+20, \\
5.0899713759141 \mathrm{e}+17\} \\
\{5.0899713759141 \mathrm{e}+17, \\
7.4498456356689 \mathrm{e}+21\} \\
\{7.4498456356689 \mathrm{e}+21, \\
8.9151485655093 \mathrm{e}+24\}\end{array}$ & $\begin{array}{l}\{1.0642144773807 \mathrm{e}+26, \\
1.3202074878402 \mathrm{e}+28\}, \\
\{1.3202074878402 \mathrm{e}+28, \\
1.7566346314932 \mathrm{e}+31\} \\
\{1.7566346314932 \mathrm{e}+31, \\
1.5793729507862 \mathrm{e}+31\}\end{array}$ \\
\hline & $\begin{array}{l}\ldots \\
\{145766, \\
23185353877\}\end{array}$ & $\begin{array}{l}\ldots \\
\{258423209929, \\
3.7808932740694 \mathrm{e}+15\}\end{array}$ & $\begin{array}{l}\ldots \\
\{4.7035849048666 \mathrm{e}+17, \\
6.7028325227805 \mathrm{e}+21\}\end{array}$ & $\begin{array}{l}\ldots \\
\{9.0420826076092 \mathrm{e}+23, \\
1.2199887882438 \mathrm{e}+28\}\end{array}$ \\
\hline & $\ldots$ & $\ldots$ & $\ldots$ & $\ldots$ \\
\hline \multirow[t]{2}{*}{5} & $\begin{array}{l}\text { \{20320471, } \\
218352494\}, \\
\{218352494, \\
1716075\}, \\
\{1716075, \\
18975807\}\end{array}$ & $\begin{array}{l}\{4.3558742668949 \mathrm{e}+15, \\
3.8682476949284 \mathrm{e}+14\}, \\
\{3.8682476949284 \mathrm{e}+14, \\
33441522639584\}, \\
\{33441522639584, \\
277824847716\}\end{array}$ & $\begin{array}{l}\{7.7166969721346 \mathrm{e}+21, \\
7.5381204301427 \mathrm{e}+21\}, \\
\{7.5381204301427 \mathrm{e}+21, \\
4.8961733296621 \mathrm{e}+17\}, \\
\{4.8961733296621 \mathrm{e}+17, \\
7.206061040019 \mathrm{e}+21\}\end{array}$ & $\begin{array}{l}\{1.5037659345117 \mathrm{e}+29, \\
1.1036562121772 \mathrm{e}+26\}, \\
\{1.1036562121772 \mathrm{e}+26, \\
1.2699412657154 \mathrm{e}+28\}, \\
\{1.2699412657154 \mathrm{e}+28, \\
1.6991514990518 \mathrm{e}+31\}\end{array}$ \\
\hline & $\begin{array}{l}\ldots \quad\{142301, \\
221721214\}\end{array}$ & $\begin{array}{l}\ldots \\
\{4.6736182577216 \mathrm{e}+16, \\
30504328435867\}\end{array}$ & $\begin{array}{l}\ldots \\
\{1.0573657348642 \mathrm{e}+26, \\
1.0018315799464 \mathrm{e}+25\}\end{array}$ & $\begin{array}{l}\ldots \\
\{2.2013576196466 \mathrm{e}+33, \\
2.2665573573324 \mathrm{e}+34\}\end{array}$ \\
\hline
\end{tabular}

Selanjutnya setelah di bentuk window maka akan dipilih fingerprint dari nilai terkecil pada setiap window, berdasarkan literatur yang ada nilai fingerprint apabila menemukan nilai terkecil yang sama maka akan diambil salah satu. Hasil dari fingerprint pada rolling hash k-gram ditampilkan pada Tabel 8.

Tabel 8. Fingerprint pada Rolling Hash K-Gram

\begin{tabular}{|c|c|c|c|c|c|}
\hline \multirow{2}{*}{ id } & \multicolumn{5}{|c|}{ k-gram } \\
\hline & $k=2$ & $k=3$ & & & $k=7$ \\
\hline 1 & $\begin{array}{l}1310,1201,1225 \\
\ldots \\
1294\end{array}$ & $\begin{array}{l}14510,13325,13585 \ldots \\
14976\end{array}$ & $\begin{array}{l}1756935, \\
1645092 \\
\ldots \\
1737290\end{array}$ & 1613645, & $\begin{array}{l}212590455, \quad 195252219, \\
199057406 \\
\ldots \\
190951712\end{array}$ \\
\hline 2 & $\begin{array}{l}1182,1175,1171 \\
\ldots \\
1353\end{array}$ & $\begin{array}{l}\text { 13099, 13022, } 12993 \ldots \\
12932\end{array}$ & $\begin{array}{l}1586264, \\
1573335 \\
\ldots \\
1565943\end{array}$ & 1576918, & $\begin{array}{l}191939200,190808260, \\
190374721 \\
\ldots \\
189480282\end{array}$ \\
\hline .. & $\ldots$ & $\ldots$ & $\ldots$ & & $\ldots$ \\
\hline 5 & $\begin{array}{l}1220,1311,1183 \\
\ldots \\
1339\end{array}$ & $\begin{array}{l}13532,14518,13125 \ldots \\
13587\end{array}$ & $\begin{array}{l}1638555, \\
1589476 \\
\ldots \\
1645356 \\
\end{array}$ & 1758066, & $\begin{array}{l}198266501,212727337, \\
192327889 \\
\ldots \\
199089347\end{array}$ \\
\hline
\end{tabular}


Berikut hasil dari fingerprint yang didapatkan dari window yang terbentuk pada rolling hash n-gram, hasil fingerprint ditampilkan pada Tabel 9.

Tabel 9. Fingerprint pada Rolling Hash N-Gram

\begin{tabular}{lllll}
\hline \multirow{2}{*}{ id } & \multicolumn{1}{c}{ unigram } & \multicolumn{1}{c}{ bigram } & \multicolumn{1}{c}{ trigram } & \multicolumn{1}{c}{ four-gram } \\
\cline { 2 - 5 } 1 & 1753739, & 34175488468955, & $6.671997059701 \mathrm{e}+20$, & $1.903598627415 \mathrm{e}+32$, \\
& 19996634, & $5.7052741634162 \mathrm{e}+18$, & $9.7506657090256 \mathrm{e}+24$, & $2.7819787230115 \mathrm{e}+36$, \\
& 280281927580 & $5.4619018510354 \mathrm{e}+18$ & $1.5583443418327 \mathrm{e}+30$ & $2.5097291459649 \mathrm{e}+35$ \\
& $\ldots$ & $\ldots$ & $\ldots$ & $\ldots$ \\
& 190951712 & $3.5732617008670 \mathrm{e}+14$ & $7.1420267032046 \mathrm{e}+20$ & $1.0794979859123 \mathrm{e}+27$ \\
\hline 2 & 1784000, & 3160471761062, & $5.0899713759141 \mathrm{e}+17$, & $1.0642144773807 \mathrm{e}+26$, \\
& 1783430, & 287223799208, & $7.4498456356689 \mathrm{e}+21$, & $1.3202074878402 \mathrm{e}+28$, \\
& 145766 & $3.7808932740694 \mathrm{e}+15$ & $8.9151485655093 \mathrm{e}+24$ & $1.5793729507862 \mathrm{e}+31$ \\
& $\ldots$ & $\ldots$ & $\ldots$ & $\ldots$ \\
& 1788924 & 258423209929 & $4.7035849048666 \mathrm{e}+17$ & $9.0420826076092 \mathrm{e}+23$ \\
\hline$\ldots$ & $\ldots$ & $\ldots$ & $\ldots$ & $\ldots$ \\
\hline 5 & 20320471, & $3.8682476949284 \mathrm{e}+14$, & $7.5381204301427 \mathrm{e}+21$, & $1.1036562121772 \mathrm{e}+26$, \\
& 1716075, & 33441522639584, & $4.8961733296621 \mathrm{e}+17$, & $1.2699412657154 \mathrm{e}+28$, \\
& 14837 & 277824847716 & $7.206061040019 \mathrm{e}+21 \ldots$ & $1.6079668527932 \mathrm{e}+30$ \\
& $\ldots$ & $\ldots$ & $1.0573657348642 \mathrm{e}+26$ & $\ldots$ \\
& 2301135907 & $4.7907955632875 \mathrm{e}+16$ & & $2.2013576196466 \mathrm{e}+33$ \\
\hline
\end{tabular}

\subsection{Jaccard Similarity}

Berdasarkan hasil fingerprint pada setiap dokumen, selanjutnya dihitung kesamaan antara dokumen satu dengan yang lainnya, hasil tingkat kesamaan dihitung menggunakan Jaccard Similarity dengan perhitungan misalnya dokumen 1 terhadap dokumen 2 pada k-gram 2, diketahui jumlah fingerprint dokumen 1 sebanyak 111 dan fingerprint dokumen 2 sebanyak 87 dan fingerprint yang sama antara dua dokumen tersebut adalah 62 sehingga perhitungannya pada persamaan 4 sebagai berikut.

$$
\begin{aligned}
& J S(X, Y)=\frac{|\mathrm{X} \cap \mathrm{Y}|}{|\mathrm{X}|+|\mathrm{Y}|-|\mathrm{X} \cap \mathrm{Y}|} \\
& J S(X, Y)=\frac{62}{198-62} \\
& J S(X, Y)=0.456
\end{aligned}
$$

\subsection{Hasil \& Perbandingan}

Berdasarkan hasil dari tingkat similarity yang dihitung menggunakan Jaccard Similarity dapat ditampilkan perbandingan dari nilai similarity berdasarkan perbedaan nilai parameter pada k-gram, perbandingan tingkat similarity ditampilkan pada Gambar 2. 
Citec Journal, Vol. 7, No. 2, Juli 2020

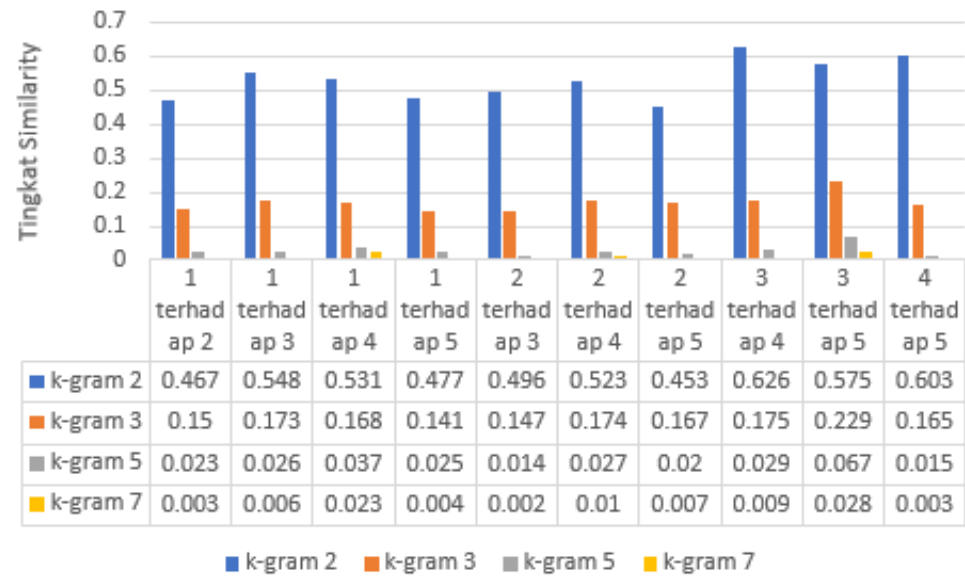

Gambar 2. Perbandingan Tingkat Similarity Berdasarkan Nilai K-Gram

Selain hasil similarity, didapatkan hasil waktu kecepatan pemrosesan dari tahap text preprocessing, algoritma Winnowing dan menghitung Jaccard Similarity terhadap dokumen yang dibandingkan, hasil kecepatan pemrosesan ditampilkan pada Gambar 3.

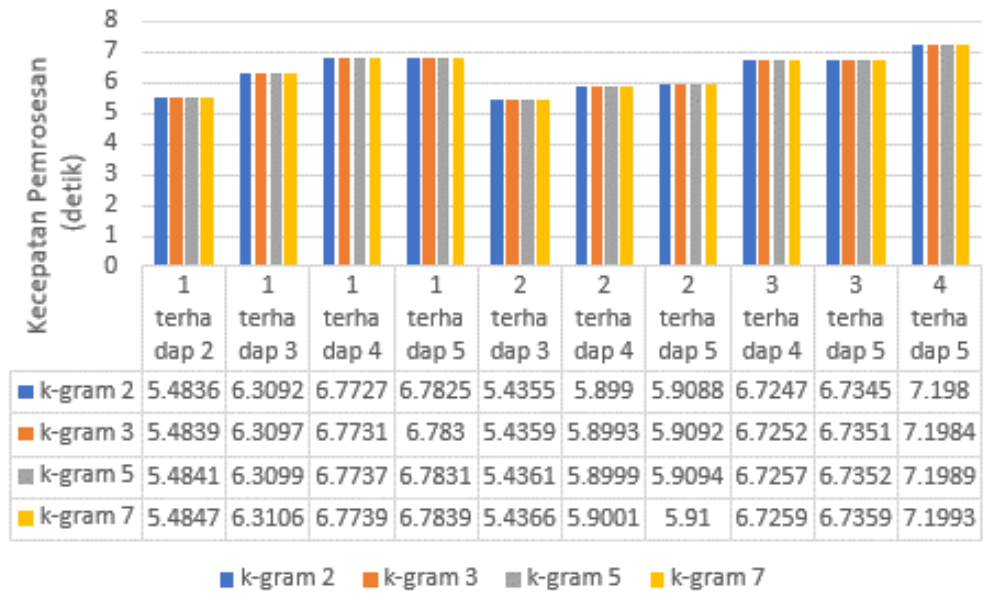

Gambar 3. Perbandingan Kecepatan Pemrosesan Berdasarkan Nilai K-Gram

Berikut ditampilkan hasil tingkat similarity terhadap dokumen yang dibandingkan berdasarkan nilai dari n-gram, hasil perbandingan tingkat similarity ditampilkan pada Gambar 4.

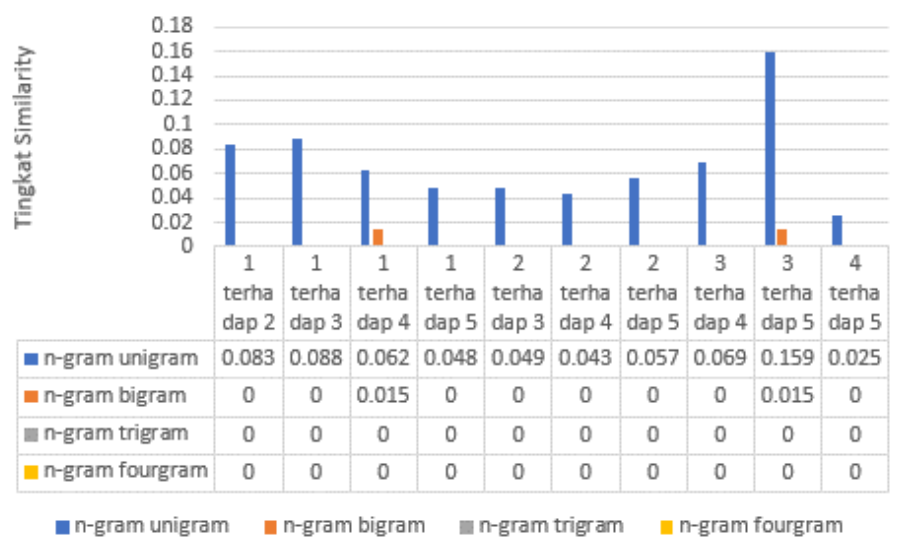

Gambar 4. Perbandingan Tingkat Similarity Berdasarkan Nilai N-Gram 
Perhitungan dari kecepatan waktu pemrosesan terhadap pemrosesan variasi n-gram ditampilkan pada Gambar 5.

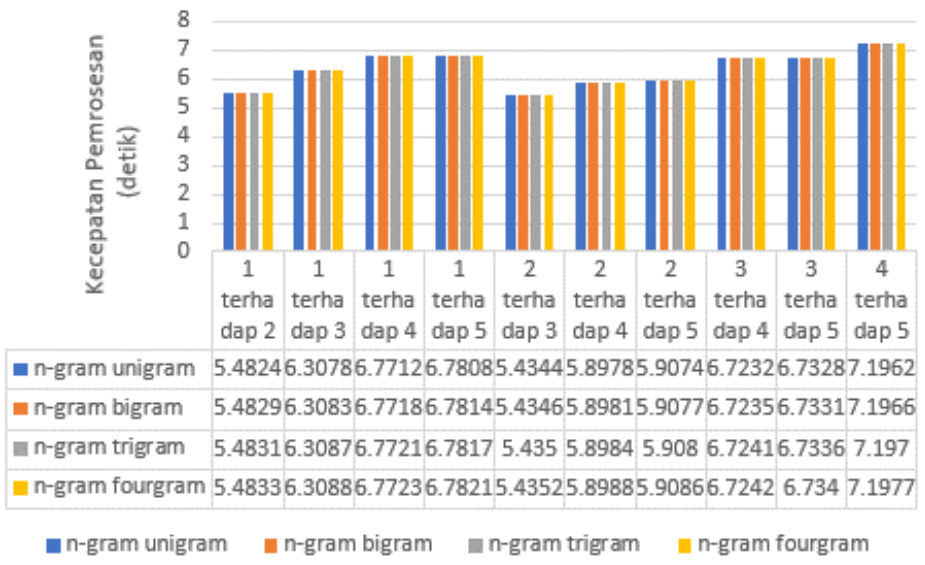

Gambar 5. Perbandingan Kecepatan Pemrosesan Berdasarkan Nilai N-Gram

Penelitian penerapan algoritma Winnowing sebelumnya [13] tidak menggunakan variasi penentuan jumlah pemotongan karakter atau kata, berdasarkan hasil pada penelitian sebelumnya terdapat hasil tingkat similarity yang mendominasi pada $0 \%$ sehingga perlu dilakukan pemilihan jumlah $k$ atau $n$ terbaik untuk mengetahui penggunaan parameter yang optimal. Penelitian terkait [15] menggunakan nilai fingerprint dari nilai terkecil pada setiap window tanpa memilih nilai fingerprint yang sama serta menggunakan nilai pemotongan string k-gram berdasarkan huruf dengan melakukan pengujian menggunakan nilai $k 5$ dan 8 hasilnya pada nilai $k=5$ menunjukkan hasil yang tidak relevan pada perbandingan kesamaan dokumen karena pada beberapa pengujian hasilnya melebihi $100 \%$ karena memperoleh fingerprint yang sama sangat tinggi dan tidak menerapkan perhitungan Jaccard Similarity dan berbeda pada penerapan $k=8$ dengan hasil nilai tengah $8.79 \%$ pada beberapa pengujian yang dilakukan. Perbandingan terhadap penelitian tersebut, dengan pengujian yang dilakukan pada penelitian ini dengan variasi nilai $k$ hasilnya tetap di jarak 0.0 sampai 1 atau $0 \%$ sampai 100\% walaupun menggunakan nilai $k$ kecil.

Setelah didapatkan hasil similarity dapat diketahui bahwa penggunaan nilai $k$ pada $\mathrm{k}$ gram dengan nilai kecil akan menaikkan nilai tingkat similarity dan semakin besar nilai $k$ pada kgram akan memperkecil nilai similarity serta didapatkan rata-rata nilai tingkat similarity berdarkan nilai pengujian terhadap nilai $\mathrm{k}$, pada $k=2$ sebesar $0.5299, k=3$ sebesar $0.1689, k=5$ sebesar 0.0283 dan $k=7$ sebesar 0.0095 . Hasil pada penerapan n-gram dengan pemotongan unigram mendominasi hasil nilai dibawah 0.10 atau $10 \%$ namun ketika diterapkan dengan bigram, trigram dan four-gram mendominasi nilai tingkat similarity 0 atau $0 \%$ dengan detail nilai ratarata pada setiap pengujian yaitu pada unigram sebesar 0.0683 , bigram sebesar 0.003 , trigram sebesar 0.000 dan four-gram sebesar 0.000 .

Berdasarkan kecepatan pemrosesan waktu pada k-gram tidak terlihat perbedaan yang signifikan terhadap pada penerapan n-gram, dengan nilai rata-rata waktu pemrosesan pada $k=2$ memiliki 6.32485 detik, $k=3$ memiliki 6.32528 detik, $k=5$ memiliki 6.3256 detik dan $k=7$ memiliki 6.32609 detik. Sedangkan pada n-gram didapatkan rata-rata waktu pemrosesan pada unigram memiliki 6.3234 detik, bigram memiliki 6.3238 detik, trigram memiliki 6.32417 detik dan four-gram memiliki 6.3245 detik. 


\section{KESIMPULAN}

Penerapan algoritma Winnowing dengan teknik pemotongan string menggunakan k-gram memiliki tingkat nilai similarity yang tinggi namun ketika nilai jumlah $k$ semakin besar akan mengurangi tingkat nilai similarity dengan hasil rata-rata pada $k=2$ sebesar $0.5299, k=3$ sebesar $0.1689, k=5$ sebesar 0.0283 dan $k=7$ sebesar 0.0095. Penerapan pemotongan string berdasarkan kata menggunakan n-gram pada penerapan unigram memiliki rata-rata tingkat similarity sebesar 0.0683 sedangkan bigram memiliki tingkat nilai similarity 0.003 , serta pada trigram dan fourgram memiliki tingkat kesamaan sebesar 0.000. Pada perbandingan kecepatan pemrosesan waktu pada k-gram dan n-gram tidak terlihat perbedaan yang signifikan dan keduanya mendominasi pada kecepatan waktu selama 6 detik.

\section{SARAN}

Berdasarkan penelitian yang dilakukan, belum dilakukan tentang perbandingan dari perbedaan penerapan dari nilai window. Sehingga dapat dilakukan penelitian lebih lanjut tentang penggunaan nilai perbedaan tersebut untuk mengetahui hasil perbandingannya.

\section{DAFTAR PUSTAKA}

[1] Sunardi., Yudhana, A., Mukaromah, I. A., 2018, Implementasi Deteksi Plagiarisme Menggunakan Metode N-Gram Dan Jaccard Similarity Terhadap Algoritma Winnowing, Jurnal Transmisi, No. 3, Vol. 20, Hal. 105

[2] ALAMSYAH, N., 2017, Perbandingan Algoritma Winnowing Dengan Algoritma Rabin Karp Untuk Mendeteksi Plagiarisme Pada Kemiripan Teks Judul Skripsi, Technologia Jurnal Ilmiah, No. 3, Vol. 8, Hal. 124

[3] Harjanta, J., Tri, A., 2015, Preprocessing Text untuk Meminimalisir Kata yang Tidak Berarti dalam Proses Text Mining, Jurnal Informatika Upgris, No. 1, Vol. 1

[4] Hariri, F. R., Utami, E., Amborowati, A., 2015, Learning Vector Quantization untuk Klasifikasi Abstrak Tesis, Citec Journal, No. 2, Vol. 2.

[5] Hariri, F. R., Pamungkas, D. P., 2016, Self Organizing Map-Neural Network untuk Pengelompokan Abstrak, Citec Journal, No. 2, Vol. 3

[6] Wirayasa, I. P. M., Wirawan, I. M. A., Pradnyana, A., 2019, Algoritma Bastal: Adaptasi Algoritma Nazief \& Adriani Untuk Stemming Teks Bahasa Bali, Jurnal Nasional Pendidikan Teknik Informatika (JANAPATI), No. 1, Vol. 8

[7] Pamungkas, H. Y., Fitrianingsih., 2019, Deteksi Similaritas Dokumen Ilmiah Menggunakan Algoritma Rabin-Karp, Jurnal Ilmiah Informatika Komputer, No. 3, Vol. 24, Hal. 209-219

[8] Negoro, W. A., Amalia, F., Santoso, E., 2019, Pengembangan Aplikasi Resep Masakan dengan Rekomendasi berdasarkan Bahan-Bahan Makanan Berbasis Web, Jurnal Pengembangan Teknologi Informasi dan Ilmu Komputer No. 9, Vol. 3, Hal. 9212-9221

[9] Khidfi, M. N., Isnawaty., Sari, J. Y., 2018, Rancang bangun aplikasi pendeteksian kesamaan pada dokumen teks menggunakan algoritma Enhaced Confix Stripping dan Algoritma Winnowing, SemanTIK Univ Haluoelo, No. 2, Vol. 4, no. 2, Hal. 1-10

[10] Sukmana, A., Kusrini., Sunyoto, A., 2018, Perbandingan Pengunaan Stemming Pada Deteksi Kemiripan Dokumen Menggunakan Metode Rabin Karp Dan Jaccard Similarity, Seminar Nasional Teknologi Informasi dan Multimedia 2018, Yogyakarta, 2 Februari 
[11] Maskur., Putra, D. Q., Hayatin, N., 2019, Deteksi Kemiripan Dokumen Proposal Penelitian Dan Pengabdian Menggunakan Algoritma Biword Winnowing, Jurnal Informatika Polinema, No. 3, Vol. 6, Hal. 43-48

[12] Faisal, M., Nugroho, F., El Sulthan, M. M., Amini, F., Hariyadi, M. A., Sedayu, A., 2020, Plagiarism detection using manber and winnowing algorithm, International Journal of Advanced Science and Technology, No. 6, Vol. 29 Special Issue, Hal. 2130-2136.

[13] Jarwati., Prihandoko, A. C., Yulia R, W. E., 2017, Penerapan Algoritma Winnowing pada Sistem Rekomendasi Penetuan Dosen Pembimbing Skripsi (Studi Kasus: Prodi Sistem Informasi Universitas Jember Jember), Berkala SAINSTEK Jurnal, No. 1, Vol. 5, Hal. 1120.

[14] Wibowo, R. K., Hastuti, K., 2016, Penerapan Algoritma Winnowing Untuk Mendeteksi Kemiripan Teks pada Tugas Akhir Mahasiswa, Techno.com, No. 4, vol. 15, Hal. 303-311.

[15] Ilham., Pasnur., 2017, Penerapan Algoritma Winnowing Untuk Mendeteksi Kemiripan Pada Karya Tulis Mahasiswa, Jurnal Teknologi Informasi dan Komunikasi, No. 2, Vol. 7, Hal. 131-136

[16] Prasidhatama, A., Suryaningrum, K. M., 2018, Perbandingan Algoritma Nazief \& Adriani Dengan Algoritma Idris Untuk Pencarian Kata Dasar, Jurnal Teknologi dan Manajemen Informatika, No. 1, Vol. 4, Hal. 1-4

[17] Adriani, M., Asian, J., Nazief, B., Tahaghoghi, S. M. M., Williams, H. E., 2007, Stemming Indonesian: A confix-stripping approach, ACM Transactions on Asian Language Information Processing, No. 4, Vol. 6.

[18] Sanjaya, S., Absyar, E. A., 2015, Pengelompokan Dokumen Menggunakan Winnowing Fingerprint dengan Metode K-Nearest Neighbour, Jurnal CoreIT, No. 2, Vol. 1, Hal. 5056

[19] Hasanah, U., Mutiara, D. A., 2019, Perbandingan metode cosine similarity dan Jaccard Similarity untuk penilaian otomatis jawaban pendek, Seminar Nasional SENSITIf 2019, Makassar, 16 - 17 Desember 